\title{
IRON DEFICIENCY ANEMIA AND CURRENT STATE OF KNOWLEDGE AMONG ADOLESCENT GIRLS, LAMPUNG-INDONESIA
}

\author{
Nurhayati ${ }^{1}$, Agni Laili Perdani², Eka Trismiyana ${ }^{3}$ \\ 1Lecturer in Diploma in Nursing Baitul Hikmah, Bandar Lampung-Indonesia. \\ Email: nurhayati56488@gmail.com \\ 2Lecturer in Nursing Study Program, Institute of Nursing Science, Indonesian Nurse Association (STIKep-PPNI) \\ West Java, Indonesia. Email: agni.perdani@gmail.com \\ 3Lecturer in Diploma in Nursing Malahayati, Bandar Lampung-Indonesia. Email: eka_najla03@yahoo.com
}

\begin{abstract}
Background: Anemia is a condition with lower hemoglobin and hematocrit levels. The number of iron deficiency in Indonesia among children aged 5 to 14 years is still quite high at $26.4 \%$. Less knowledge in adolescent caused by the consumption of unhealthy food or light snacks.

Purpose: To describe the relationship of Iron deficiency anemia and current state of knowledge among adolescent girls in 1st Mesuji Junior High School.

Methods: The type of this research is an observational study with a cross-sectional method. The population of this study was members of all adolescent girls in class VIII and IX at 1st Mesuji Junior High School with the total is 87 respondents. Data collected by a questionnaire and analyzed used chi-square.

Results: The most of the respondents $47(54 \%)$ had poor knowledge about Iron deficiency anemia and experienced of Iron deficiency anemia 44 (50.6\%) with $p$-value $=0.001$.

Conclusion: There is a relationship between Iron deficiency anemia and current state of knowledge among adolescent girls, Mesuji Junior High School in 2018. It is recommended for school management to further improve health promotion or counseling about Iron deficiency anemia in adolescent girls, especially in prevention.
\end{abstract}

\section{Keywords: Knowledge, iron deficiency, anemia, adolescent}

\section{INTRODUCTION}

Anemia is one of the health problems throughout the world, especially in developing countries including Indonesia with the rate of iron deficiency anemia on children aged $5-14$ years is $26.4 \%$ higher than those aged 15 - 24 years with only 18.4\% (Riskesdas, 2013).

Anemia often occurs in the community, especially among adolescents and pregnant women. According to data from the World Health Organization (WHO) in 2013, the total anemia cases in young women is still quite high with the prevalence from $40-88 \%$. Anemia is a condition of low hemoglobin and hematocrit levels and caused body experienced hypoxia as a result of the decreased ability to transport oxygen from blood (Kirana, 2011). Iron, folate, vitamin B12 and vitamin A deficiencies, chronic inflammation, parasitic infections, and inherited disorders can cause anemia with the signs and symptoms including fatigue, weakness, dizziness, and drowsiness (WHO, 2019).
The need for teenagers for iron is quite high because there is an increase in nutrient requirements for growth compared to other age groups. The consequences of anemia in adolescents effected on the long term during motherhood while in the short time for adolescents, anemia significantly disrupts the concentration of learning and also affects the number of absences to school which will ultimately affect achievement in school (Arumsari, 2008).

The long-term effect of this anemia on teenagers during pregnancy will affect the ability to fulfill the nutrients for herself and the fetus in the womb and therefore increase the frequency of complications, the risk of maternal death, prematurity rates, low birth weight (LBW), and perinatal mortality rates (Giyanti \& Wahtini, 2016). To prevent the occurrence of anemia, teenagers need to be equipped with knowledge about anemia and the pattern of adolescent food intake itself (Rahmi, 2017). Young women have a higher risk of anemia than young men. Because every month young women experience period. Women with a lot of menstruation 
for more than five days is feared to lose iron. Thus they need more replacement iron than women who have only three days and a little. The other reasons because young women often maintain their appearance for the purpose to stay slim or thin, so they diet and reduce eating. Inadequte diet that with the body's nutritional needs will cause the body to lack essential nutrients such as iron (Arisman, 2010). Based on data from the Lampung Provincial Health Office in 2016 the prevalence of anemia in adolescents is $24.6 \%$ with the highest incidence of anemia in adolescents occurring in Mesuji Regency which was equal to $36.1 \%$ while the second order was East Lampung Regency with 35.4\% (Lampung Health Province Agency 2016). According to Mesuji District Health Office data in 2016, it was found that the incidence of anemia in adolescents was the highest health problem among adolescents, with $36.1 \%$, while the second biggest problem was obesity, with the total event is $27.6 \%$. Less knowledge caused teenagers to choose unhealthy food on the outside or only consume snacks. Other causes are lack of adequate food and lack of intake food sources that contain iron, besides the consumption of adequate food but food consumed has a low bioavailability of metal so that the amount of iron absorbed by the body is lacking (Silalahi, Aritonang \& Ashar, 2016).

Based on the research conducted by Ikhmawati (2013) resulted from facts that the relationship between anemia knowledge and intake pattern to hemoglobin levels in adolescent girls in Surakarta high school dormitories obtained statistical tests used were Pearson Product Moment and Rank-Spearman test. The results showed that $76 \%$ of the knowledge about anemia in young women was classified as weak. Data on intake pattern is $52 \%$ of the frequency of eating teenage girls is classified as good, while $73.3 \%$ of young women consume poorer types of food. $\mathrm{Hb}$ level examination data of $56 \%$ of female adolescent $\mathrm{Hb}$ levels were classified as abnormal. The test results of the relationship between knowledge about anemia on $\mathrm{Hb}$ levels $\mathrm{p}$-value $=0.033$. The test results of the relationship between the frequency of eating to $\mathrm{Hb}$ levels the value of $p=0.002$. The test results of the relationship between types of food to $\mathrm{Hb}$ levels $p$-value
$=0.048$. There is a relationship between knowledge about anemia and the frequency of eating to hemoglobin levels. There is a relationship between the types of food on hemoglobin levels. The results of the pre survey conducted on seven junior high schools in Mesuji Regency showed that there are three junior high schools that have low knowledge about anemia and a high incidence of anemia, namely 2nd Mesuji Junior High School of 10 students. 50\%) about anemia is still lacking, and four people (40\%) have anemia. While in 5 Mesuji Junior High Scholl the total is six people $(60 \%)$ have less knowledge, and five people $(50 \%)$ experienced anemia.

The highest prevalence was found in 1st Mesuji Junior High Scool SMP 1 Mesuji, data showed that from 10 young women who were examined for $\mathrm{Hb}$ levels found that 7 people $(70 \%)$ had anemia and based on interview 6 people $(60 \%)$ did not know the signs and symptoms of anemia and how to avoid anemia. Teenager. This shows that the incidence of anemia in adolescents is still quite high. From these data illustrate that anemia problems, especially in young women are still quite high. Anemia is still one of the factors behind the high maternal mortality rate in Indonesia. Thus the prevention actions are to know early on whether someone is suffering from anemia or not and immediately seek measures to overcome anemia. Based on the description above, the authors feel interested in researching "The Relationship of Iron deficiency anemia and current state of knowledge among adolescent girls, 1st Mesuji Junior High School Lampung-Indonesia 2018."

\section{RESEARCH METHODS}

The type of this research is a quantitative study with a cross-sectional method. Data were collected using laboratory result to measure hemoglobin level and anemia knowledge by self-questionnaire. Respondents filled a total of ten questions with yes and no options. One point will be added for the right answer and zero points for the wrong answer with six as a cut-off point. The populations were all girls in class VIII and IX at Mesuji 1 Public High School, and 87 respondents are included and participated in this study.

Nurhayati' Lecturer in Diploma in Nursing Baitul Hikmah, Bandar Lampung-lndonesia.

Email: nurhayati56488@gmail.com

Agni Laili Perdani ${ }^{2}$ Lecturer in Nursing Study Program, Institute of Nursing Science, Indonesian Nurse Association (STIKep-PPNI) West Java, Indonesia. Email: agni.perdani@gmail.com

Eka Trismiyana ${ }^{3}$ Lecturer in Diploma in Nursing Malahayati, Bandar Lampung-Indonesia. Email: eka_najla03@yahoo.com 
Malahayati International Journal of Nursing and Health Science, Volume 02, No.1, March 2019: 20-24 IRON DEFICIENCY ANEMIA AND CURRENT STATE OF KNOWLEDGE AMONG ADOLESCENT GIRLS, LAMPUNG-INDONESIA

\section{RESEARCH RESULTS}

Table 1. Frequency Distribution Of current state of knowledge ( $\mathrm{N}=87$ )

\begin{tabular}{lcc}
\hline Category & Frequency & Percentage \\
\hline Good & 40 & 46 \\
Poor & 47 & 54 \\
Total & 87 & 100 \\
\hline
\end{tabular}

Table 2. Frequency Distribution of Hemoglobin Level $(\mathrm{N}=87)$

\begin{tabular}{lll}
\hline Category & Frequency & Percentage \\
\hline Anemia & 44 & 50.6 \\
Normal & 43 & 49.4 \\
Total & $\mathbf{8 7}$ & 100 \\
\hline
\end{tabular}

Table 3. The Relationship of Iron deficiency anemia and current state of knowledge

\begin{tabular}{|c|c|c|c|c|c|c|c|c|}
\hline \multirow{3}{*}{$\begin{array}{l}\text { Current state } \\
\text { of knowledge }\end{array}$} & \multicolumn{5}{|c|}{ Hemoglobin Level } & Total & \multirow[t]{3}{*}{$p$-value } & \multirow{3}{*}{$\begin{array}{c}\text { OR } \\
\text { Cl } 95 \%\end{array}$} \\
\hline & \multicolumn{2}{|c|}{ Normal } & \multicolumn{2}{|c|}{ Anemia } & \multirow[t]{2}{*}{$\mathbf{N}$} & \multirow[t]{2}{*}{$\%$} & & \\
\hline & $\mathrm{n}$ & $\%$ & $n$ & $\%$ & & & & \\
\hline Good & 28 & 70 & 12 & 30 & 40 & 100 & 0,001 & 4,978 \\
\hline Poor & 15 & 31,9 & 32 & 68,1 & 47 & 100 & & $(1,998-$ \\
\hline Total & 43 & 49,4 & 44 & 50,6 & 87 & 100 & & $12,403)$ \\
\hline
\end{tabular}

In this study out of 87 adolescent girls, 47 (54\%) had poor knowledge about anemia (Table 1), and more than a half, 44 (50.6\%) experienced anemia (Table 2). From 40 respondents with good anemia knowledge, $28(70 \%)$ of them had normal hemoglobin level while 12 adolescent girls $(30 \%)$ suffer from anemia (Table 3 ). Out of 47 students with inadequate knowledge, 15 $(31.9 \%)$ of them had normal hemoglobin level while $32(68.1 \%)$ experienced anemia (Table 3). The results of the analysis using chi-square showed that there is a relationship between anemia knowledge and anemia cases with Odd Ratio (OR) equal to 4.978 it means that adolescents girl with proper education will have the opportunity not experienced anemia by four times greater than with inadequate knowledge.

\section{DISCUSSION}

Iron deficiency anemia and current state of knowledge among adolescent girls in 1st Mesuji Junior High School and the results of this study are semilar by a survey from Caturiyantiningtiyas (2015) that more than half respondents with a good current state of knowledge. Adolescent girls with an inadequate understanding of anemia caused by the lack of health promotion or health education from family or school and also limited resources from mass media. Furthermore, the results of this study similar with research by Amany \& Rokhanawati (2017) conducted in the adolescent girl at Yogyakarta which showed more than students had normal hemoglobin level compared with students with anemia. According to researchers, several factors contributed including lack of intake of nutrients, especially iron. Iron requirements for young women are higher than in young men because of the

Nurhayati Lecturer in Diploma in Nursing Baitul Hikmah, Bandar Lampung-lndonesia.

Email: nurhayati56488@gmail.com

Agni Laili Perdani ${ }^{2}$ Lecturer in Nursing Study Program, Institute of Nursing Science, Indonesian Nurse Association (STIKep-PPNI) West Java, Indonesia. Email: agni.perdani@gmail.com

Eka Trismiyana ${ }^{3}$ Lecturer in Diploma in Nursing Malahayati, Bandar Lampung-Indonesia. Email: eka_najla03@yahoo.com 
Malahayati International Journal of Nursing and Health Science, Volume 02, No.1, March 2019: 20-24 IRON DEFICIENCY ANEMIA AND CURRENT STATE OF KNOWLEDGE

AMONG ADOLESCENT GIRLS, LAMPUNG-INDONESIA

menstrual process. Also, they focus on body appearance. Thus they go on a false diet with less intake nutrition. This study found there was a relationship between Iron deficiency anemia and current state of knowledge among adolescent girls in Mesuji 1 st Middle School students in 2018 with pvalue $=0.001$ and $\mathrm{OR}=4,978$.

The results of in accordance with the theory put forward by $L$ Green in Notoatmodjo (2012) that the behavioral factors are determined by several factors, one of which is predisposing factors, namely factors that facilitate or predispose a person's behavior to knowledge. The results of this study are in line with the research conducted by Caturiyantiningtiyas (2015) showed that there is a relationship between knowledge, attitudes, and behavior with the incidence of anemia in adolescent girls $(p=0.03)$ respondents with inadequate knowledge about anemia, tend to experience anemia.

Otherwise, respondents with proper education, tend not to have anemia because knowledge affected the type of food consumption thus they make an effort to fulfill their nutritional needs including iron yet, respondents with poor knowledge tend to experience anemia because they do not know the dangers of anemia so they do not consume foods that can prevent anemia. However, this study also found that respondents who had poor knowledge but with normal hemoglobin level related with family influenced that always fulfill their nutritional needs very well and they do not go on a diet program, so they consume food according to their body needs. In contrast, in this study described those adolescent girls with good knowledge but experienced anemia because they are on menstruation period. Therefore, the hemoglobin level in the blood is still under normal, the food consumption mostly street food around the school environment contain with lack of nutritious element and very rarely to bring food from home.

\section{CONCLUSION}

Most of the respondents had poor knowledge about anemia and had a low hemoglobin level. There is a relationship between anemia knowledge and anemia cases of anemia among adolescent girls at 1st Mesuji Junior High School in 2018, with $p$-value = 0.001 and $\mathrm{OR}=4.978$.

\section{SUGGESTIONS}

Healthcare

Professionals

in

Schools: To implement the essential health education for adolescents in schools related to diet to prevent Iron deficiency anemia and adolescents: To increase the understanding of the side effects of anemia on both short and long term and enhance the knowledge about anemia and find out how to prevent anemia and practice by consuming nutritious, balanced foods. For Future Research: To to examine other related factors associated with the anemia cases from external and internal including such parental income or adolescent diet.

\section{REFERENCES}

Arisman, M. B. (2010). Obesitas, Diabetes Militus \& Dislipidemia.

Arumsari, E. (2008). Faktor risiko anemia pada remaja putri peserta program pencegahan dan penanggulangan anemia gizi besi (PPAGB) di kota Bekasi. Bogor: Skripsi IPB.

Caturiyantiningtiyas, T. (2015). Hubungan Antara Pengetahuan, Sikap Dan Perilaku Dengan Kejadian Anemia Remaja Putri Kelas X Dan Xi Sma Negeri 1 Polokarto (Doctoral Dissertation, Universitas Muhammadiyah Surakarta).

Dinas Kesehatan Provinsi Lampung. (2016). Pravelensi Kejadian Anemia Pda Remaja tahun 2016.

Giyanti, F., \& Wahtini, S. (2016). Pengaruh Pemberian Tablet Fe Terhadap Kenaikan Kadar Hemoglobin Remaja Putri Dengan Anemia Di Smk Negeri I Ponjong Kabupaten Gunungkidul Tahun (Doctoral Dissertation, Universitas' Aisyiyah Yogyakarta).

Nurhayati' Lecturer in Diploma in Nursing Baitul Hikmah, Bandar Lampung-lndonesia.

Email: nurhayati56488@gmail.com

Agni Laili Perdani ${ }^{2}$ Lecturer in Nursing Study Program, Institute of Nursing Science, Indonesian Nurse Association (STIKep-PPNI) West Java, Indonesia. Email: agni.perdani@gmail.com

Eka Trismiyana ${ }^{3}$ Lecturer in Diploma in Nursing Malahayati, Bandar Lampung-Indonesia. Email: eka_najla03@yahoo.com 
Ikhmawati, Y. (2013). Hubungan Antara Pengetahuan Tentang Anemia Dan Kebiasaan Makan Terhadap Kadar Hemoglobin Pada Remaja Putri Di Asrama Sma Mta Surakarta (Doctoral dissertation, Universitas Muhammadiyah Surakarta).

Kirana, D. P. (2011). Hubungan Asupan Zat Gizi dan Pola Menstruasi dengan kejadian anemia pada remaja putri di SMA N 2 Semarang (Doctoral dissertation, Diponegoro University).

Kusmiran, E. (2011). Kesehatan reproduksi remaja dan wanita. Jakarta: Salemba Medika, 21.

Notoatmodjo, S. (2008). Metodologi Penelitian Cetakan 4. Jakarta: Rineka Cipta.

Notoatmodjo, S. (2010). Metodologi penelitian kesehatan.

Notoatmodjo, S. (2012). Promosi kesehatan dan perilaku kesehatan. Jakarta: Rineka Cipta, 45-62.
Rahmi, H. I. (2017). Hubungan Pengetahuan Tentang Anemia, Dukungan Sekolah Dan Asupan Zat Gizi Dengan Kejadian Anemia Remaja Di Smk Negeri 3 Padang Tahun 2017 (Doctoral Dissertation, Universitas Andalas).

Riset kesehatan dasar (Riskesdas).(2013). Jakarta: Badan Penelitian dan Pengembangan Kesehatan

Runia, Y. O. D. E. N. C. A. (2008). Faktor-Faktor Yang Berhubungan Dengan Keracunan Pestisida Organofosfat, Karbamat Dan Kejadian Anemia Pada Petani Hortikultura Di Desa Tejosari Kecamatan Ngablak Kabupaten Magelang

Silalahi, V., Aritonang, E., \& Ashar, T. (2016). Potensi Pendidikan Gizi dalam Meningkatkan Asupan Gizi pada Remaja Putri yang Anemia di Kota Medan. Jurnal Kesehatan Masyarakat, 11(2), 295-301.

World Health Organization (WHO). 2019. Anemia. Retrieved 15 January 2019 from https://www.who.int/topics/anaemia/en/

Nurhayati' Lecturer in Diploma in Nursing Baitul Hikmah, Bandar Lampung-Indonesia.

Email: nurhayati56488@gmail.com

Agni Laili Perdani ${ }^{2}$ Lecturer in Nursing Study Program, Institute of Nursing Science, Indonesian Nurse Association (STIKep-PPNI) West Java, Indonesia. Email: agni.perdani@gmail.com

Eka Trismiyana ${ }^{3}$ Lecturer in Diploma in Nursing Malahayati, Bandar Lampung-Indonesia. Email: eka_najla03@yahoo.com 